\title{
Phase Relations Inferred from Field Data for Mn Pyroxenes and Pyroxenoids*
}

\author{
Philip E. Brown ${ }^{1}$, Eric J. Essene, and Donald R. Peacor \\ Department of Geological Sciences, The University of Michigan, Ann Arbor, MI 48109, USA
}

\begin{abstract}
Electron microprobe analysis of manganese silicates from Balmat, N.Y., has helped elucidate phase relations for $\mathrm{Mn}$-bearing pyroxenes and pyroxenoids. A compilation of these data along with published and unpublished analyses for phases plotting on the $\mathrm{CaSiO}_{3}-\mathrm{MgSiO}_{3}-\mathrm{MnSiO}_{3}$ and $\mathrm{CaSiO}_{3}-$ $\mathrm{FeSiO}_{3}-\mathrm{MnSiO}_{3}$ faces of the $\mathrm{RSiO}_{3}$ tetrahedron has constrained the subsolidus phase relations. For the system $\mathrm{CaSiO}_{3}-\mathrm{FeSiO}_{3}-\mathrm{MnSiO}_{3}$, the compositional gaps between bustamite/hedenbergite, bustamite/ rhodonite and rhodonite/pyroxmangite are constrained for middle-upper amphibolite facies conditions and extensive solid solutions limit possible three phase fields. For the $\mathrm{CaSiO}_{3}-\mathrm{MgSiO}_{3}-\mathrm{MnSiO}_{3}$ system much less data are available but it is clear that the solid solutions are much more limited for the pyroxenoid structures and a continuum of compositions is inferred for clinopyroxenes from diopside to kanoite $\left(\mathrm{MnMgSi}_{2} \mathrm{O}_{6}\right)$ for amphibolite facies conditions $\left(T=650^{\circ} \mathrm{C}\right)$. At lower temperatures, Balmat kanoites are unstable and exsolve into $C 2 / c$ calciumrich $\left(\mathrm{Ca}_{0.68} \mathrm{Mn}_{0.44} \mathrm{Mg}_{0.88} \mathrm{Si}_{2} \mathrm{O}_{6}\right)$ and $\mathrm{C} 2 / \mathrm{c}$ calciumpoor $\left(\mathrm{Ca}_{0.12} \mathrm{Mn}_{1.02} \mathrm{Mg}_{0.86} \mathrm{Si}_{2} \mathrm{O}_{6}\right)$ phases. At temperatures of $300-400^{\circ} \mathrm{C}$ the calcium-poor phase subsequently has undergone a transformation to a $P 2_{1} / c$ structure; this exsolution-inversion relationship is analogous to that relating augites and pigeonites in the traditional pyroxene quadrilateral. Rhodonite coexisting with Mn-clinopyroxenes is compositionally restricted to $\mathrm{Mn}_{0.75-0.95} \mathrm{Mg}_{0.0-0.15} \mathrm{Ca}_{0.05-0.13} \mathrm{SiO}_{3}$. For the original pyroxene + rhodonite assemblage, the $\mathrm{Mg}$ and $\mathrm{Ca}$ contents of the rhodonite are fixed for
\end{abstract}

\footnotetext{
I Present address: U.S. Geological Survey, 959 National Center, Reston, VA 22092, USA

Reprint requests to: P.E. Brown

* Contribution No. 363, from the Mineralogical Laboratory, Department of Geological Sciences, The University of Michigan, Ann Arbor MI 48109, USA
}

a specific $P(6 \mathrm{kbars})-T\left(650^{\circ} \mathrm{C}\right)-X\left(\mathrm{H}_{2} \mathrm{O}\right)-X\left(\mathrm{CO}_{2}\right)$ by the coexistence of talc + quartz and calcite + quartz respectively.

\section{Introduction}

As part of an on-going study of metamorphism in the Adirondack Mountains in northern New York state, a study of the phase relations of the ore and country rock in the Balmat-Edwards zinc district was undertaken. Results of the sphalerite geobarometry and calcite-dolomite thermometry have been previously reported (Brown et al. 1978). In the course of the study, several manganese-rich pods from the metasedimentary sequence were investigated. These pods contained the $\mathrm{Mn}$-amphibole tirodite as well as rhodonite, manganoan calcite and a manganeserich pyroxene. The magnesium-rich rhodonite has been described by Peacor et al. (1978). This paper is in part a report on the petrologic study of these manganese bearing pyroxenes and pyroxenoids from Balmat but more importantly it provides an integration of these data with that of other workers on synthetic and natural Mn-bearing systems. Data of this compilation leads to constraints on the subsolidus phase relations of $\mathrm{Mn}$-bearing pyroxenes and pyroxenoids.

\section{Balmat - Geology and Metamorphism}

The Balmat-Edwards zinc district occurs in the dominantly metasedimentary terrain northwest of the Highlands-Lowlands boundary as summarized by DeWaard (1969) for the northwest Adirondacks. The apparently remobilized, premetamorphic, Mississippi Valley type ore body has been localized in structurally favorable positions within the complexly interlayered sequence of impure siliceous carbonates and evaporites typical of the southern Grenville Province (Lea and Dill 1968). The majority of the units consist of variably 
diopsidic dolomites with accessory tremolite, phlogopite, calcite, anhydrite and primary talc. Occasional units of calcitic marble and massive anhydrite occur throughout the sequence. The scattered manganese-rich pods are associated with a variety of the mappable units.

As reported earlier (Brown et al. 1978; Bohlen and Essene 1977; Hoffman and Essene 1978; Valley and Bohlen 1979) pressures $(P)$ and temperatures $(T)$ have been fixed for the peak of metamoxphism at $P=6.5 \pm 0.5 \mathrm{~kb}$ and $T=625^{\circ} \pm 25^{\circ} \mathrm{C}$. These values were derived from sphalerite barometry, $\mathrm{K}$ feldspar-plagioclase, magnetite-ilmenite and calcite-dolomite thermometry and the presence of sillimanite in the adjacent metapelites. Nearly all the minerals show some evidence (mainly exsolution) of re-equilibration at lower temperatures (down to $300^{\circ} \mathrm{C}$ ) and pressures, necessitating reintegration techniques to infer peak $P-T$ conditions. Details of the pressure determination, calcite-dolomite thermometry and analytical techniques can be found in Brown et al. (1978). The remaining thermometry and reintegration techniques are discussed in Bohlen and Essene (1977)

\section{Balmat Manganese Minerals}

The scattered manganese-rich pods which are found both on the surface as well as underground in the Gouverneur Talc and St. Joe Minerals Corporation mines contain a variety of manganese minerals. They are perhaps best known for the manganoan cummingtonite-"tirodite" (as shown by Ross et al. 1969, this is a misnomer; the correct name is dannemorite, Leake 1978) and the violet-colored variety of manganoan tremolite locally called "hexagonite", but contain, as well, assemblages including:

$\mathrm{Mn}$-pyroxene $+\mathrm{Mg}$-rhodonite + talc + quartz;

Mn-pyroxene + Mg-rhodonite + manganoan calcite + quartz + anhydrite.

The crystal chemistry and petrogenesis of the unusually magnesium-rich, iron-poor rhodonite has been discussed by Peacor et al. (1978).

Electron microprobe analyses of the pyroxene yielded compositions between $\mathrm{Ca}_{0.43} \mathrm{Mn}_{0.69} \mathrm{Mg}_{0.82} \mathrm{Si}_{2} \mathrm{O}_{6}$ and $\mathrm{Ca}_{0.28} \mathrm{Mn}_{0.82} \mathrm{Mg}_{0.89} \mathrm{Si}_{2} \mathrm{O}_{6}$ (Fig. 6). In all cases, the Mn-pyroxene exhibits a blue optical schiller indicating the presence of submicroscopic exsolution, analogous in scale to that of the peristerite feldspars. Gordon et al. (in press) report the results of X-ray diffraction and analytical electron microscopy (AEM) which have yielded compositions for the two sets of exsolution lamellae. The X-ray diffraction study proved the existence of coexisting $P 2_{1} / C$ and $C 2 / c$ phases. Analytical electron microscopy yielded compositions of $\mathrm{Ca}_{0.12} \mathrm{Mn}_{1.02} \mathrm{Mg}_{0.86} \mathrm{Si}_{2} \mathrm{O}_{6}$ for the primitive and $\mathrm{Ca}_{0.68} \mathrm{Mn}_{0.44} \mathrm{Mg}_{0.88} \mathrm{Si}_{2} \mathrm{O}_{6}$ for the $C$-centered phase respectively (Fig. 6). Although not yet fully calibrated, the AEM results are believed to be more accurate than the compositions inferred from $\mathrm{X}$-ray diffraction data, mainly due to site occupancy restrictions inher- ent in the X-ray refinement process. In any case, the above data delimit a low temperature solvus between $C 2 / c$ and $P 2_{1} / c$ pyroxenes in the $\mathrm{CaSiO}_{3}-\mathrm{MgSiO}_{3}-$ $\mathrm{MnSiO}_{3}$ system analogous to that found between augites and pigeonites in part of the $\mathrm{CaSiO}_{3}-$ $\mathrm{MgSiO}_{3}-\mathrm{FeSiO}_{3}$ system. This analogy can be carried still further since the $P 2_{1} / c$ phase has antiphase domains, indicating the existence of a $C 2 / c-P 2_{1} / c$ inversion as also exhibited by pigeonites. Heating experiments performed in the AEM yielded an approximate inversion temperature of $330^{\circ} \mathrm{C}$ for this manganeserich pyroxene. The presence of this exsolution-inversion relationship coupled with recent reports of coexisting manganese pyroxenes and pyroxenoids (Mason 1973; Hodgson 1975; Peters et al. 1977) implied that enough data are now available to examine phase relations among manganese-bearing single-chain silicates and allow a comparison with the $\mathrm{CaSiO}_{3}-\mathrm{MgSiO}_{3}-$ $\mathrm{FeSiO}_{3}$ subsystem. Published and unpublished mineral analyses were therefore compiled for pyroxenes and pyroxenoids within the system $\mathrm{CaSiO}_{3}-$ $\mathrm{MgSiO}_{3}-\mathrm{FeSiO}_{3}-\mathrm{MnSiO}_{3}$ and are presented in Figs. 1 and 2. In general, compositional data and phase identifications were taken directly from the literature, but in a few cases identifications have been reassigned to more likely phases; these will be detailed below. Analyses have been excluded for phases that contained significant amounts of both iron and magnesium since they would plot in the interior of the $\mathrm{RSiO}_{3}$ tetrahedron and we wish to evaluate equilibria in the ternary subsystems. This restriction resulted in the removal of most of the pyroxenes but few of the pyroxenoids. Finally it should be pointed out that the following discussion considers only metamorphic conditions and does not include data from igneous rocks.

\section{Discussion}

Figure 1 is a compilation of mineral analyses which plot in the Ca-Fe-Mn single-chain silicate ternary system. Several features of this diagram should be clarified. The Ca-rich, nearly manganese-free bustamites were originally described as "iron wollastonite" (Tilley 1937 b, 1948); however Matsueda $(1973,1974)$ has shown that these minerals coexist with wollastonite and Rapoport and Burnham (1972) show that the phases with these compositions are isostructural with bustamite. The term ferrobustamite refers to those compositions with $\mathrm{Fe}>\mathrm{Mn}$. The compositional field for extremely Ca-rich bustamites probably extends from iron-free to manganese-free compositions at high temperatures. Relationships in the calcic corner of the ternary are unclear at low temperatures, possi- 


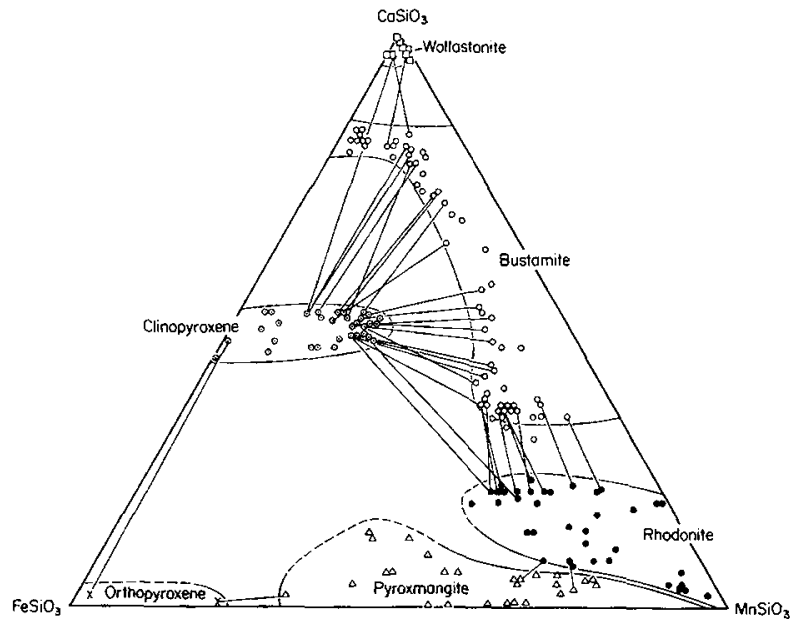

Fig. 1. Compilation of published and unpublished analyses for $\mathrm{Ca}-\mathrm{Fe}-\mathrm{Mn}$ single chain silicates. Tie lines join coexisting phases. $P=4-8$ kbar and $T=600^{\circ} \pm 100^{\circ} \mathrm{C}$ for most of the points. Sources for data in Figs. 1 and 2, in addition to analyses in Table 1: Chopin (1978); Deer et al. (1978); Ford and Bradley (1913); Henderson and Glass (1936); Hietanen (1938); Hodgson (1975); Huntington (1975); Jaffe et al. (1978); Klein (1966); Krough (1977); Lee (1955); Lindsley et al. (1969); Mason (1973, 1975); Matsueda (1973, 1974); Ohashi and Finger (1978); Ohashi et al. (1975); Peters et al. (1978); Rapoport and Burnham (1972); Scoullar and Wall (unpubl.); Shimazaki and Bunno (1978); Sundius (1931); Tilley (1937a, 1937b, 1948); Winter et al. (in press)

bly permitting a compositional gap in the bustamites, Matsueda (1974), although textures between coexisting $\mathrm{Fe}$-rich and $\mathrm{Mn}$-rich bustamites are not convincingly primary and suggest non-equilibrium replacement relations. Rutstein and White (1971) and Rutstein (1971) provide largely synthesis data on relationships among calcium-rich pyroxenoids which can be reconciled with the equilibrium results discussed below.

The extent of solid solution of $\mathrm{FeSiO}_{3}$ in bustamite and the width of the compositional gap between bustamite and hedenbergite are not well known as a function of temperature. The majority of the tielines between the hedenbergite and bustamite fields are from the work of Hodgson (1975) and Mason (1973) on the Broken Hill district of Australia. In these specimens, the primary bustamite, plus or minus primary hedenbergite, has formed under lower granulite facies conditions and the bustamite subsequently exsolved into an intergrowth of clinopyroxene and more manganoan bustamite. This exsolved intergrowth has been plotted in Fig. 1. Hodgson (1975) infers that the observed exsolution and the pronounced textural and mineralogical changes in the ore and gangue assemblages are due to retrograde metamorphic conditions. He assigns a lower limit to significant exsolution of $500^{\circ}-550^{\circ} \mathrm{C}$. Point counting to determine the original composition of the pyroxen- oid (now exsolved bustamite and hedenbergite) that coexisted with primary clinopyroxene would allow the solvus width to be limited for peak temperatures$600^{\circ}-700^{\circ} \mathrm{C}$.

Experiments on the join hedenbergite-ferrosilite by Lindsley and Munoz (1969) and others have demonstrated that for amphibolite facies conditions the solvus between ortho- and clinopyroxenes extends from the $\mathrm{FeSiO}_{3}$ corner to $\mathrm{Fs}_{55} \mathrm{Wo}_{45}$. Ferrosilite is unstable below about $11 \mathrm{~kb}$ at $750^{\circ} \mathrm{C}$ with respect to fayalite + quartz (Bohlen et al. 1980 b; Smith 1972) and, as a consequence of this, there is no stable chain silicate in the iron corner of the $\mathrm{CaSiO}_{3}-\mathrm{FeSiO}_{3}$ $\mathrm{MnSiO}_{3}$ ternary (Fig. 1). Bohlen and Boettcher (1980) and Smith (1972) have further demonstrated that 5 to $10 \% \mathrm{MgSiO}_{3}$ solid solution is sufficient to stabilize ferrosilite at $6-7 \mathrm{kbar}$ for temperatures of $750^{\circ} \mathrm{C}$. Bohlen et al. (1980a) have reversed the ferrosilite to olivine + quartz reaction for $\mathrm{Mn}$-containing bulk compositions of $\mathrm{Fs}_{95}-\mathrm{Rh}_{5}$ and $\mathrm{Fs}_{90}-\mathrm{Rh}_{10}$. They found that the equilibrium boundary lies at $9.8 \mathrm{~kb}$ and $750^{\circ} \mathrm{C}$ for $\mathrm{Fs}_{90} \mathrm{Rh}_{10}$. This effect is of the right direction and order of magnitude to be consistent with Krogh's (1977) report of a manganoan ferrosilite from granulite facies rocks in Sweden. This pyroxene coexists with a pyroxferroite which limits the iron content of the pyroxmangite structure to less than 70 mole percent $\mathrm{FeSiO}_{3}$ for the conditions of metamorphism. Krogh (1977) estimates values of $T$ $750^{\circ} \mathrm{C}$ and $P-9 \mathrm{~kb}$ for the peak event based on two pyroxene geothermometry, garnet-orthopyroxene thermometry and the $\mathrm{Al}_{2} \mathrm{O}_{3}$ content of orthopyroxene as well as the presence of primary sillimanite. When the activity/composition relationships are known for the $\mathrm{MnSiO}_{3}-\mathrm{FeSiO}_{3}$ orthopyroxenes, it will be possible to calculate a point on the activity/composition diagram for pyroxmangites/pyroxferroites assuming equilibrium for this pair. Calibration of this system is of great interest in geobarometry for fixing minimum pressure limits in orthopyroxene and pyroxenoid-bearing rocks.

Figure 2 is a compilation of analyses of single chain silicates in the system $\mathrm{CaSiO}_{3}-\mathrm{MgSiO}_{3}-$ $\mathrm{MnSiO}_{3}$. In general, analyses with $\mathrm{Mg}: \mathrm{Fe}$ ratio less than $8: 1$ were discarded. The lack of abundant data precludes constraining the phase relations as well as was done for the $\mathrm{Ca}-\mathrm{Fe}-\mathrm{Mn}$ subsystem. Metamorphosed manganese deposits which are often relatively iron-free and local manganoan pods in regional metamorphics provide the best opportunities to find minerals whose analyses plot within this ternary diagram.

Electron microprobe analyses for the 4 pyroxenerhodonite pairs are given in Table 1. The most calcic clinopyroxene-rhodonite pair is from Ducktown, Tennessee. The peak $P-T$ for this occurrence as deter- 
Table 1. Electron microprobe chemical analyses. All analyses were obtained using an ARL-EMX microprobe with PET, LIF and TAP crystal spectrometers. An Ortec current digitizer was used to stabilize the beam current. An accelerating voltage of $15 \mathrm{kv}$ and sample current of 0.005-0.01 microamps were used in all analyses. Standards are all well characterized natural silicates

\begin{tabular}{|c|c|c|c|c|c|c|c|c|c|}
\hline & 1 & 2 & 5 & 4 & 5 & 6 & 7 & 7 & 9 \\
\hline $\mathrm{SiO}_{2}$ & 53.27 & 49.95 & 53.3 & 48.9 & 54.1 & 48.5 & 52.09 & 54.36 & 47.66 \\
\hline $\mathrm{Al}_{2} \mathrm{O}_{3}$ & - & 0.18 & 0.12 & n.d. & 0.07 & n.d. & 0.25 & 0.11 & 0.06 \\
\hline $\mathrm{FeO}$ & 3.42 & 3.35 & 1.33 & 0.62 & 0.12 & 0.15 & 0.28 & 0.42 & 0.37 \\
\hline $\mathrm{MnO}$ & 10.25 & 35.91 & 18.3 & 41.6 & 11.4 & 45.0 & 21.06 & 25.93 & 42.62 \\
\hline $\mathrm{MgO}$ & 12.99 & 2.29 & 14.6 & 4.50 & 14.4 & 1.61 & 14.21 & 15.42 & 4.72 \\
\hline $\mathrm{CaO}$ & 22.58 & 7.03 & 12.4 & 5.01 & 20.4 & 6.00 & 10.41 & 5.17 & 4.58 \\
\hline Total & 102.51 & 98.71 & 100.05 & 100.63 & 100.49 & 101.26 & 98.30 & 101.41 & 100.01 \\
\hline $\mathrm{Si}$ & 0.99 & 1.06 & 1.01 & 1.01 & 1.01 & 1.01 & 1.00 & 1.03 & 1.00 \\
\hline $\mathrm{Fe}$ & 0.05 & 0.06 & 0.02 & 0.01 & - & - & 0.01 & 0.01 & - \\
\hline $\mathrm{Mn}$ & 0.16 & 0.64 & 0.29 & 0.73 & 0.18 & 0.79 & 0.35 & 0.42 & 0.75 \\
\hline $\mathrm{Mg}$ & 0.36 & 0.07 & 0.41 & 0.14 & 0.40 & 0.05 & 0.41 & 0.44 & 0.15 \\
\hline $\mathrm{Ca}$ & 0.45 & 0.16 & 0.25 & 0.11 & 0.40 & 0.13 & 0.22 & 0.11 & 0.10 \\
\hline $\mathrm{O}$ & 3.00 & 3.00 & 3.00 & 3.00 & 3.00 & 3.00 & 3.00 & 3.00 & 3.00 \\
\hline $\mathrm{Mn}$ & 0.15 & 0.73 & 0.29 & 0.74 & 0.20 & 0.80 & 0.36 & 0.42 & 0.75 \\
\hline $\mathrm{Mg}$ & 0.40 & 0.08 & 0.44 & 0.15 & 0.40 & 0.06 & 0.42 & 0.46 & 0.15 \\
\hline $\mathrm{Ca}$ & 0.45 & 0.19 & 0.27 & 0.11 & 0.40 & 0.14 & 0.22 & 0.12 & 0.10 \\
\hline
\end{tabular}

1) Cpx from Ducktown Tenn.

2) Rhod from Ducktown Tenn.

3) Cpx Anal. B5-10-80.2 II from Buritirama, Brazil: Peters et al. 1977

4) Rhod Anal. B5-10-80.2 II from Buritirama, Brazil: Peters et al. 1977

5) Cpx Anal. B5-10-97.8 IV from Buritirama, Brazil: Peters et al. 1977

6) Rhod Anal. B5-10-97.8 IV from Buritirama, Brazil: Peters et al. 1977

7) Cpx from Balmat, N.Y.: Gordon et al., in press

8) Cpx from Balmat, N.Y.

9) Rhod from Balmat, N.Y.: Peacor et al. 1979

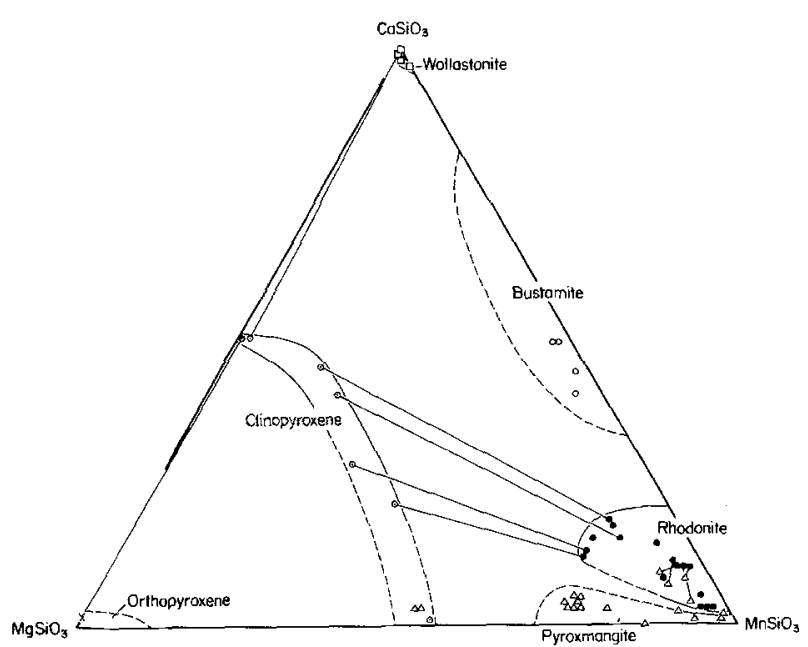

Fig. 2. Analyses for $\mathrm{Ca}-\mathrm{Mg}-\mathrm{Mn}$ pyroxenes and pyroxenoids. $P=3-6 \mathrm{kbar}$ and $T=600^{\circ} \pm 100^{\circ} \mathrm{C}$. See text for discussion of specific compositions

mined by silicate equilibria and calcite-dolomite thermometry is 6 kilobars at $550^{\circ} \mathrm{C}$ (Nesbitt and Essene 1979 , in press). The next two lower-calcium pairs are reported from a manganese deposit in Brazil by Peters et al. (1977) who assign a temperature for this deposit of $550^{\circ} \pm 50^{\circ} \mathrm{C}$ based on $\mathrm{Ca}-\mathrm{Mn}$ carbonate equilibria and the presence of the isobaric, invariant assemblage diopside + tremolite + calcite + dolomite + quartz. Fluid inclusion freezing point determinations and homogenization temperatures coupled with the temperatures inferred from phase equilibria yield a pressure of 3 kilobars for this deposit. The final pyroxene-rhodonite pair is from the Balmat-Edwards occurrence. Here the pre-exsolution bulk composition of the pyroxene has been chosen since the conditions for the peak of metamorphism resemble the $P-T$ conditions of the other occurrences outlined above.

A pyroxene of the composition $\mathrm{Mn}_{1.06} \mathrm{Mg}_{0.92} \mathrm{Ca}-$ ${ }_{0.02} \mathrm{Si}_{2} \mathrm{O}_{6}$ has been reported by Kobayashi (1977) from Hokkaido, Japan, and has been given the name kanoite. It occurs as minute grains intergrown with manganoan cummingtonite in a manganese deposit metamorphosed to hornblende hornfels/middle amphibolite facies conditions. The two analyses represented by triangles in the clinopyroxene field of Fig. 2 are considered by Peters et al. (1977), to be pyroxmagnites and deserve comment. The crystal chemistry of pyroxmangite makes it unlikely that such $\mathrm{Mg}$-rich compositions corresond to a pyroxenoid structure and 

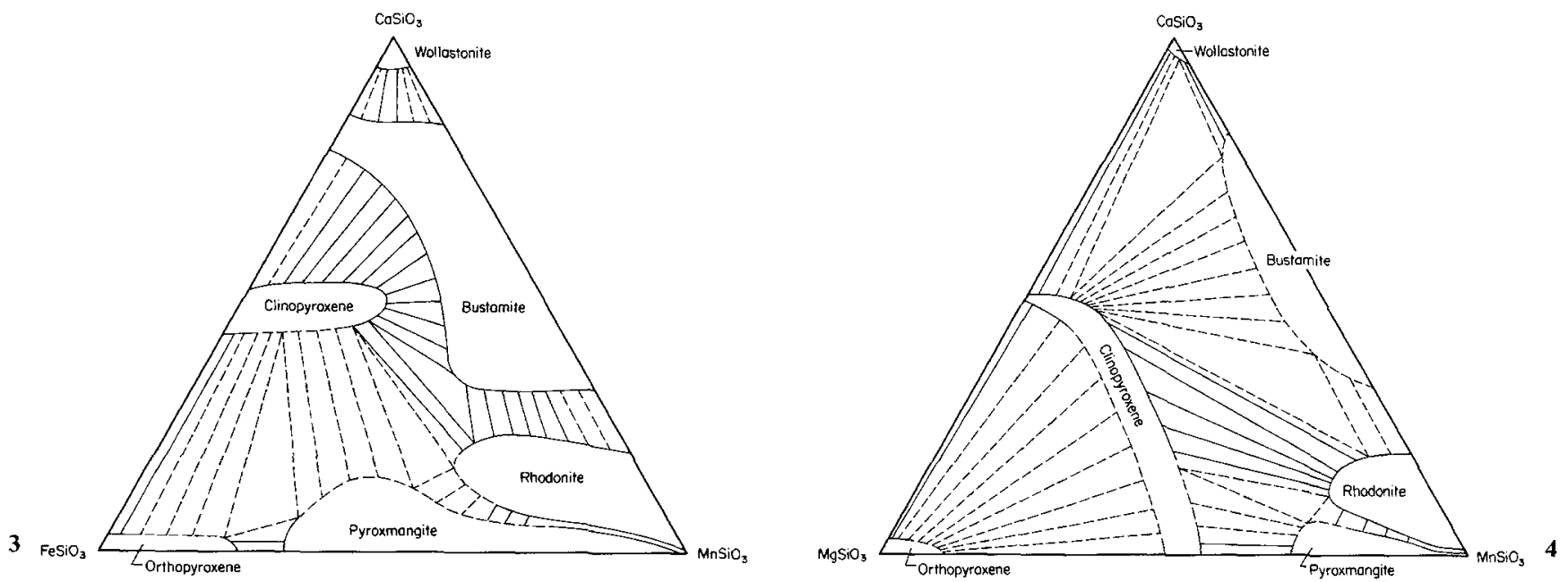

Fig. 3. Observed (-) and inferred (---) tie lines and three phase fields for the $\mathrm{Ca}-\mathrm{Fe}-\mathrm{Mn}$ single-chain silicates for amphibolite/granulite facies conditions, $P=3-6 \mathrm{kbar}$ and $T=600^{\circ} \pm 50^{\circ} \mathrm{C}$. The orthopyroxene field has been shown schematically; for these $P-T$ the pure iron metasilicate composition does not have a chain silicate structure

Fig. 4. Observed (-) and inferred (--) tie lines and three phase fields for the $\mathrm{Ca}-\mathrm{Mg}-\mathrm{Mn}$ pyroxenes and pyroxenoids for amphibolite/ granulite facies conditions, $P=3-6 \mathrm{kbar}$ and $T=600^{\circ} \pm 50^{\circ} \mathrm{C}$

they may be kanoite. As determined by Burnham (1971) and verified by Ohashi and Finger (1975), pyroxmangite has seven crystallographically distinct octahedral sites. The sites conventionally designated M5 and $\mathrm{M} 7$ are large and are occupied by large $\mathrm{Ca}$ or $\mathrm{Mn}$ atoms. Conversely M6 is the smallest and will be occupied by a small $\mathrm{Mg}$ atom. The remaining octahedral sites, M1-M4, may not, on the average, each be occupied by more than about $1 / 3$ of a small magnesium atom and still support the pyroxmangite structure. Thus the maximum amount of magnesium allowable in the pyroxmangite structure is approximately $(4 \times 1 / 3+1) / 7=33 \%$ of the octahedral cations, in good agreement with the observed compositions (Fig. 2), excluding those of Peters et al. (1977). Further, Kobayashi (1977), reports the pair kanoite-pyroxmangite which would directly limit the compositional gap for his $P-T$ conditions; unfortunately the composition of the pyroxmangite has not been determined. Replacing magnesium by the slightly larger ferrous iron atom essentially doubles the allowed substitution for manganese and only the M5 and M7 sites contain appreciable $\mathrm{Mn}$ and $\mathrm{Ca}-\mathrm{a}$ composition reflected by the pyroxmangite from Sweden (Fig. 1) (Krogh 1977).

Most of the rest of the pyroxmangites plotted are from Peters et al. (1977) and Winter et al. (in press), the latter having studied the Bald Knob deposit in North Carolina. The four pyroxmangite/rhodonite pairs which plot near $5 \% \mathrm{MgSiO}_{3}, 10 \% \mathrm{CaSiO}_{3}$ are reported by Chopin (1978) from a blueschist terrain in the Alps; as discussed below, the pyroxmangite structure has been stabilized by the high $P$, low $T$ environment. Finally, it should be pointed out that the bustamite field is poorly constrained by natural data and that the boundaries have been drawn on a crystal-chemical basis; specifically, a maximum of $5 / 6$ and a minimum of $1 / 3$ of the 6 sites in bustamite must be occupied by a large calcium atom (Ohashi and Finger 1978; Mason 1975). The limit on the substitution of magnesium is unknown, the boundary has been drawn at $1 / 2$ the mole percent limit exhibited by iron, a relationship consistent with that for the pyroxmangites.

Using these raw data, stability fields and tie lines were inferred and have been delineated in Figs. 3 and 4. Consider first the fairly well established $\mathrm{Ca}-\mathrm{Fe}-$ Mn subsystem (Fig. 3). This diagram has been constructed for middle to upper amphibolite facies conditions, i.e., $P=3-6$ kilobars and $T=600^{\circ} \pm 50^{\circ} \mathrm{C}$. The solid tie lines and field boundaries are from the natural occurrences shown in Fig. 1; the dashed lines are inferred. The boundaries of the compositional fields are dashed where unconstrained by the natural or experimental data. The significant features of this diagram are the extensive solid solution ranges of all phases except wollastonite and consequently the limited extent of the inferred three phase fields. The experimental results of Bohlen et al. (1980a) suggest that there is no stability field, even for manganoan compositions, for the orthopyroxene structure at the pressure specified for Fig. 3 and therefore the boundary has been dotted. Bowen et al. (1933) and Lindsley and Munoz (1969) report that hedenbergite inverts 
at about $960^{\circ} \mathrm{C}$ to a wollastonite structure although this assignment was made on the basis of power X-ray patterns. The high temperature polymorph of hedenbergite has a bustamite structure - the differences in powder X-ray patterns between wollastonite and bustamite are slight enough to escape easy detection. Note also that the bustamite field cuts the possible clinopyroxene-wollastonite tie line, a situation that does not occur when only a little magnesium is added to the system (Fig. 4).

Figure 4 shows the inferred field boundaries and tie lines for the $\mathrm{Ca}-\mathrm{Mg}-\mathrm{Mn}$ ternary. This diagram has been constructed for essentially the same pressuretemperature conditions as Fig. 3. The compositional ranges of all the phases except perhaps the clinopyroxene have decreased in extent relative to the corresponding ranges of Fig. 3, increasing the sizes of the primary three phase fields and establishing tie lines between clinopyroxene and wollastonite, a common assemblage. Experimental work on the relationship between the polymorphs johannsenite and bustamite has been reported by Morimoto et al. (1977) and Lamb et al. (1972). Morimoto et al. determined an upper limit for the stability of johannsenite at $830^{\circ} \mathrm{C}$; however as no reversal was obtained, they may have significantly overstepped the equilibrium because their experiments were done in air and run durations were insufficient to allow for equilibrium at lower temperatures. As shown subsequently by Lamb et al., johannsenite does invert to a bustamite structure with increasing temperature; however their high pressure reversals are imprecise enough that no certain extrapolation is possible to low pressure environments. Their work does suggest that johannsenite may be metastable in most crustal $P-T$ regimes, except at the lowest temperatures, at least for the composition $\mathrm{CaMnSi}_{2} \mathrm{O}_{6}$.

The relationship between rhodonite and pyroxmangite at elevated $P-T$ has been examined in three separate studies. Ito (1972) examined the system $\mathrm{MnSiO}_{3}-\mathrm{MgSiO}_{3}$ at liquidus and near liquidus temperatures, found a complex melting relationship, and synthesized rhodonite, pyroxmangite, clinopyroxene and orthopyroxene in the subsolidus. His boundaries for these fields at $1,200^{\circ} \mathrm{C}$ and above are synthesis ones and experimental reversals are needed in this system to experimentally limit the true equilibrium relationships. Akimoto and Syono (1972) and Maresch and Mottana (1976) studied the polymorphic transformation between rhodonite and pyroxmangite for the composition $\mathrm{MnSiO}_{3}$. Akimoto and Syono's experiments were conducted at high $P-T$ and are largely synthesis runs. They conclude that rhodonite is the only stable form of $\mathrm{MnSiO}_{3}$ under crustal conditions. Maresch and Mottana provide reversals at

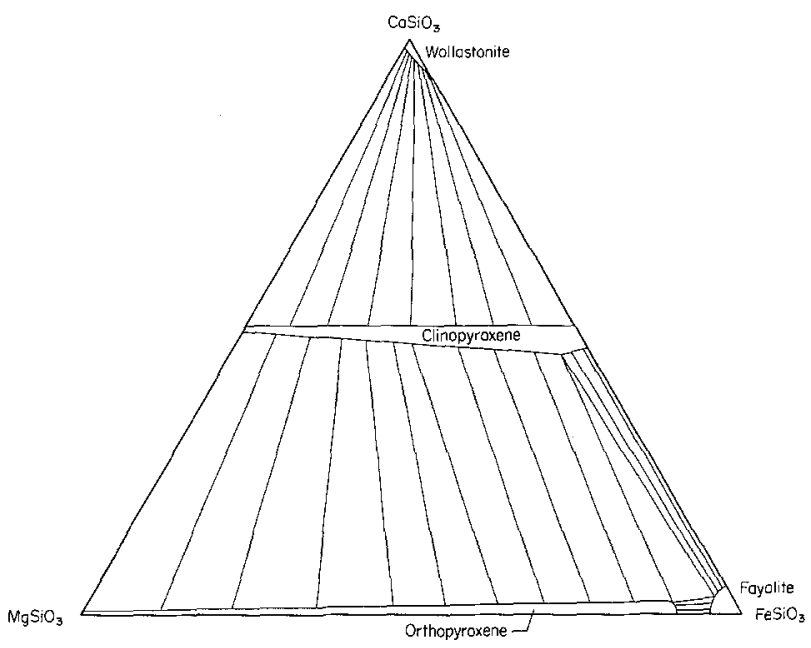

Fig. 5. $\mathrm{Ca}-\mathrm{Mg}-\mathrm{Fe}$ chain-silicate ternary for amphibolite/granulite facies conditions of $T=600^{\circ} \mathrm{C}, P=3-6 \mathrm{kbar}$. The tie lines are schematic, however broadly consistent with metamorphic $K_{\mathrm{D}}$ 's. See text for further details

3 and $6 \mathrm{~kb}$ which indicate that rhodonite should be the stable polymorph under most metamorphic conditions for the pure manganese system; however a field for pyroxmangite stability in some crustal regimes does exist at low $T$ and high $P$. Furthermore, Akimoto and Syono's reversals are consistent with Maresch and Mottana's data. Blueschist facies conditions and iron and magnesium diluents will favor the pyroxmangite structure. The rhodonite field is bounded on its high magnesium side by the pyroxene + rhodonite fields described above. Greater uncertainties occur in the more calcium-poor part of this ternary system. Assuming that the two pyroxmangites reported by Peters et al. (1977) are really pyroxenes, as discussed above, it is likely that the clinopyroxene field extends all the way from diopside to the kanoite composition at high temperature, while the pyroxmangites are restricted to lower magnesium contents. This would be consistent with the magnitudes of shrinkage for the other pyroxenoid fields in going from the iron to the magnesium system, as well as allow for the pair kanoite-pyroxmangite reported by Kobayashi (1977).

Comparison of Fig. 4 with the standard $\mathrm{Ca}-$ $\mathrm{Mg}-\mathrm{Fe}$ chain silicate ternary (Fig. 5) at similar temperatures and pressures shows that there are considerable differences in topology. The tie lines in Fig. 5 are schematic and consistent with the observed $K_{\mathrm{D}}$ 's for metamorphic pyroxenes (see for example Davidson 1968; Deer et al. 1978; Bohlen and Essene 1978). The stability field for fayalite has been approximately located consistent with the experimental work of Bohlen and Boettcher (1980). The most striking difference is that the fields for the pyroxenoids are not present 
in the $\mathrm{Ca}-\mathrm{Mg}-\mathrm{Fe}$ system. It can also be shown that phase relations for $\mathrm{Ca}-\mathrm{Mg}-\mathrm{Fe}$ pyroxenes at igneous temperatures are analogous to the phase relations of $\mathrm{Ca}-\mathrm{Mg}-\mathrm{Mn}$ pyroxenes at metamorphic temperatures.

Specifically, at igneous temperatures, a bulk composition plotting in the middle of the $\mathrm{Ca}-\mathrm{Mg}-\mathrm{Fe}$ quadrilateral will consist of a $C 2 / c$ subcalcic augite and a $C 2 / c$ pigeonite. Upon cooling, exsolution lamellae form with orthopyroxene lamellae in the augite and augite lamellae in the pigeonite. Further cooling produces a $C 2 / c$ to $P 2 / c$ transition in the pigeonite with the formation of antiphase domains (Morimoto and Tokonami 1969). In a plutonic setting, annealing will finally transform the $P 2_{1} / c$ pigeonite to orthopyroxene with further augite exsolution. In a volcanic setting, the pigeonite may be quenched and never " invert " to the orthopyroxene. At metamorphic temperatures, the phase relations are as shown in Fig. 5. The coexisting pyroxenes are a subcalcic augite and an orthopyroxene with only very minor exsolution lamellae.

At metamorphic temperatures in the system $\mathrm{Ca}-$ $\mathrm{Mg}-\mathrm{Mn}$ (Fig. 4), a small orthopyroxene field occurs at the composition $\mathrm{Mg}_{2} \mathrm{Si}_{2} \mathrm{O}_{6}$. The diagram shows a continuum of compositions from $\mathrm{CaMgSi}_{2} \mathrm{O}_{6}$ to $\mathrm{MnMgSi}_{2} \mathrm{O}_{6}$ with the Balmat sample plotting at a point analogous to pigeonite in the $\mathrm{Ca}-\mathrm{Mg}-\mathrm{Fe}$ quadrilateral. Upon cooling, this pyroxene unmixes to a more calcic $C 2 / c$ phase and a calcium-poor $C 2 / c$ species folowed by the $C 2 / c$ to $P 2 / c$ transformation in the Ca-poor phase as documented by Gordon et al., (in press) producing antiphase domains. The further transformation to an orthopyroxene structure is unlikely due to the low temperatures involved (kinetic barrier) and the size of the manganese atom (crystal chemical barrier). These relationships are discussed further below.

In the $\mathrm{Ca}-\mathrm{Mg}-\mathrm{Fe}$ system, the size difference between calcium and iron atoms in the M2 site of pigeonite promotes the establishment of two compositionally distinct clinopyroxenes, one the $C 2 / c$ augite, the other the calcium poor high pigeonite $(C 2 / c)$ at relatively high temperatures $\left(900^{\circ}-1,000^{\circ} \mathrm{C}\right)$. The similarity in radius of calcium and manganese on the other hand requires lower temperatures before two clinopyroxene structures are stablilized at the expense of high $C 2 / c$ pigeonite. The Balmat sample provides direct evidence for this lower temperature exsolution process and subsequent transformation.

Figure 6 shows the inferred phase relations at a retrograde temperature of about $300^{\circ} \mathrm{C}$. The kanoitelike high temperature "pigeonite" has undergone exsolution and inversion to yield $C 2 / c$ calcium-rich $P 2_{1} / c$ calcium-poor phases. The actual exsolution

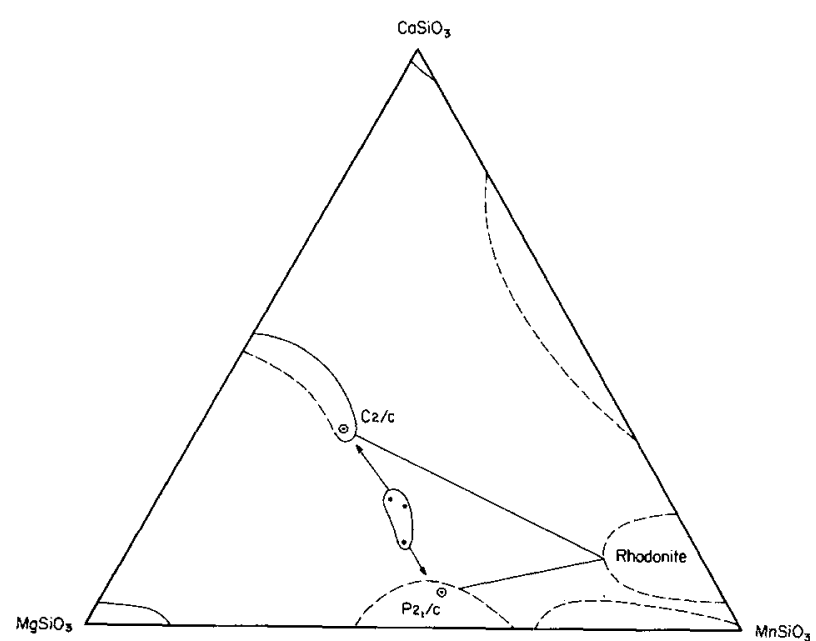

Fig. 6. $\mathrm{Ca}-\mathrm{Mg}-\mathrm{Mn}$ pyroxene and pyroxenoid compositional fields for a retrograde temperature near $300^{\circ} \mathrm{C}$. The field with three electron microprobe analyses represents the $600^{\circ} \mathrm{C}$ bulk composition of the pyroxene which has subsequently unmixed to the observed $C 2 / C$ and $P 2_{1} / C$ phases indicated by the circled dots on the figure. The compositions of these latter two points were determined by AEM

temperature is not known but must lie between the temperature of formation $\left(625^{\circ} \pm 25^{\circ} \mathrm{C}\right)$ and that of the $C 2 / c$ to $P 22_{1} / c$ transition for the calcium-poor phase $\left(325^{\circ} \mathrm{C}\right.$ ) (Gordon et al., in press).

The width of the solvus is similar to that in the $\mathrm{Ca}-\mathrm{Mg}-\mathrm{Fe}$ pyroxene quadrilateral. However, the tie line parallels the $\mathrm{Ca}-\mathrm{Mn}$ side of the diagram instead of pointing more toward the calcium corner as it would for a bulk chemistry in the analogous position in the $\mathrm{Ca}-\mathrm{Mg}-\mathrm{Fe}$ system. Again, simple pyroxene crystal chemical relations may be used to explain this observation. As manganese is added to a system starting with a bulk composition midway between enstatite and diopside, it is preferentially incorporated into the calcium-poor phase since manganese is too large to easily fit into the M1 site of the $C 2 / c$ phase, the large M2 site being filled with calcium. Thus the calcium-rich composition is "pegged" near the ideal composition of diopside while the composition of the primitive structure rapidly migrates toward the manganese corner. For the $\mathrm{Ca}-\mathrm{Mg}-\mathrm{Fe}$ system, however, the addition of iron to the same starting composition is more evenly distributed between phases since $\mathrm{Fe}$ can more easily substitute for magnesium in the M1 site of the $C 2 / c$ phase. Thus adding iron shifts both the $C 2 / c$ and $P 2 / c$ compositions toward the iron corner with the calcium-poor one shifting more rapidly since the iron can be incorporated into both cation sites. The result of this is subequal $\mathrm{Fe} / \mathrm{Fe}+\mathrm{Mg}$ ratios for the two clinopyroxenes in the $\mathrm{Ca}-\mathrm{Mg}-\mathrm{Fe}$ quadrilateral. 
Rhodonite shows extensive substitution of iron for manganese with up to 35 mole percent $\mathrm{FeSiO}_{3}$. It is unclear how much iron can be accomodated in the rhodonite structure. The Balmat rhodonites are low in iron simply because the bulk rock composition is low in iron. It is unlikely, however, that the field for iron-bearing rhodonites extends much beyond that schematically shown in Fig. 3. The maximum magnesium content possible in rhodonite is also unknown but Peacor et al. (1978) make a strong case that the Balmat sample approaches the limit for both magnesium content and degree of ordering.

To quantify further and ultimately constrain phase relationships in these ternary systems, and eventually the $\mathrm{CaSiO}_{3}-\mathrm{FeSiO}_{3}-\mathrm{MgSiO}_{3}-\mathrm{MnsiO}_{3}$ quaternary, more experimental and field related studies must be undertaken. The most fruitful experimental studies will probably be those delineating the bustamite/hedenbergite and the pyroxmangite/orthopyroxene solvi at a variety of pressures and temperatures. These solvi will allow activity/composition relationships to be deduced and applied to natural compositions for geothermometry and geobarometry.

Acknowledgements. We thank Dr. T. Peters, Dr. H. Kobayashi, Dr. C. Klein, and Dr. B. Nesbitt for providing samples that have been analyzed in this study. In addition Dr. J.S. Huebner provided a number of pyroxenoid standards which were used in the microprobe analysis. Wendy Gordon provided analyses of the Balmat pyroxene and acquired the AEM data on the exsolved compositions. We would also like to thank Dave Dill of St. Joe Minerals Corp. for saving the specimens from Balmat and making them available for our study. Finally, we would like to acknowledge the help of Dr. W. Bigelow and the staff of the Microprobe Laboratory at The University of Michigan for maintaining the microprobe and STEM in excellent working condition. Dr. J.S. Huebner is thanked for many helpful comments on an earlier draft of this manuscript.

\section{References}

Akimoto S, Syono Y (1972) High pressure transformation in $\mathrm{MnSiO}_{3}$. Am Mineral 57:76-84

Bohlen SR, Boettcher AL (1980) The effect of magnesium on orthopyroxene-olivine-quartz stability: orthopyroxene geobarometry (abstr). Trans Am Geophys Union 61 (17), 393

Bohlen SR, Boettcher AL, Dollase W, Essene EJ (1980a) The effect of manganese on olivine-quartz-orthopyroxene stability. Earth Planet Sci Lett 47:11-20

Bohlen SR, Essene EJ (1977) Feldspar and oxide thermometry of granulites in the Adirondack Highlands. Contrib Mineral Petrol 62:163-169

Bohlen SR, Essene EJ (1978) Igneous pyroxenes from metamorphosed anorthosite massifs. Contrib Mineral Petrol 65:433-442

Bohlen SR, Essene EJ, Boettcher AL (1980b) Reinvestigation and application of olivine-quartz-orthopyroxene barometry. Earth Planet Sci Lett 47:1-10

Bowen NL, Schairer JF, Posnjak E (1933) The system CaO$\mathrm{FeO}-\mathrm{SiO}_{2}$. Am J Sci 26:193-283
Brown PE, Essene EJ, Kelly WC (1978) Sphalerite geobarometry in the Balmat-Edwards district, New York. Am Mineral $63: 250-257$

Burnham CW (1971) The crystal structure of pyroxferroite from Mare Tranquillitatis. Proc Second Lunar Sci Conf. Geochim Cosmochim Acta (Suppl 2) 1: MIT Press, pp 47-57

Carpenter MA (1978) Nucleation of augite at antiphase boundaries in pigeonite. Phys Chem Minerals 2:237-251

Chopin C (1978) Oxidized and reduced parageneses in Mn-deposits of the "schistes lustres" from Haute-Maruienne (French Alps). Bull Soc Fr Mineral Cristallogr 101:514-531

Davidson LR (1968) Variation in ferrous iron-magnesium distribution coefficients of metamorphic pyroxenes from Quairading, Western Australia. Contrib Mineral Petrol 19:239-259

Deer WA, Howie RA, Zussman J (1978) Rock Forming Minerals, Vol 2 A, Single Chain Silicates. John Wiley and Sons

De Waard D (1969) Facies series and P-T conditions of metamorphism in the Adirondack Mountains. Koninkel Nederl Akademie von Wetenschappen-Amsterdam, Proceedings, Series B 72, $2: 124-131$

Ford WE, Bradley WM (1913) Pyroxmangite, a new member of the pyroxene group and its alteration product, skemmatite. Am J Sci 36:169-174

Gordon WA, Peacor DR, Brown PE, Essene EJ, Allard LF (1980) Exsolution relationships in a clinopyroxene of average composition $\mathrm{Ca}_{0.43} \mathrm{Mn}_{0.69} \mathrm{Mg}_{0.82} \mathrm{Si}_{2} \mathrm{O}_{6}$ from Baimat, New York: X-ray diffraction and scanning transmission electron microscopy. Am Mineral (in press)

Henderson EP, Glass JJ (1936) Pyroxmangite, new locality: Identity of sobralite and pyroxmangite. Am Mineral 21:273-294

Hietanen A (1938) On the petrology of Finnish quartzites. Bull Comm Geol Finlande $21: 1-119$

Hodgson CJ (1975) The geology and geological development of the Broken Hill Lode, in the New Broken Hill Consolidated Mine, Australia: Part II: Mineralogy. J Geol Soc Aust 22:33-50

Hoffman KS, Essene EJ (1978) Reevaluation of the orthopyroxene isograd, northwest Adirondacks (abstr). Geol Soc Am Abstr Progr 10:423

Huntington JC (1975) Mineralogy and petrology of metamorphosed iron-tich beds in the lower Devonian Littleton Formation, Orange Area, Massachusetts. University of Massachusetts $19: 1-106$

Ito $J$ (1972) Rhodonite-pyroxmangite peritectic along the join $\mathrm{MnSiO}_{3}-\mathrm{MgSiO}_{3}$ in air. Am Mineral 57:865-876

Jaffe HW, Robinson P. Tracy RJ (1978) Orthoferrosilite and other iron-rich pyroxenes in microperthite gneiss of the Mount Marcy area, Adirondack Mountains. Am Mineral 63:1116-1136

Kobayashi $\mathrm{H}$ (1977) Kanoite $\left(\mathrm{Mn}^{2+}, \mathrm{Mg}\right)_{2} \mathrm{Si}_{2} \mathrm{O}_{6}$, a new clinopyroxene in the metamorphic rocks from Tatehira, Oshima Peninsula, Hokkaido, Japan. J Geol Soc Japan 83:537-542

Klein C (1966) Mineralogy and petrology of the metamorphosed Wabush Iron Formation, southwestern Labrador. J Petrol $7: 246-305$

Krogh EJ (1977) Origin and metamorphism of iron formations and associated rocks, Lofoten-Vesteralen, N. Norway. I. The Vestpolltind Fe-Mn deposit. Lithos 10:243-255

Lamb CL, Lindsley DH, Grover JE (1972) Johannsenite-bustamite: inversion and stability range (abstr). Geol Soc Am Abstr Progr $4: 571-572$

Lea ER, Dill DB (1968) Zinc deposits of the Balmat-Edwards District, New York. In: Ridge JD (ed) Ore deposits of the United States, 1933-1967. Am Inst Mining Engineers, New York, pp 20-48

Leake BE (1978) Nomenclature of amphiboles. Am Mineral $63: 1023-1053$

Lee DE (1955) Mineralogy of some Japanese manganese ores. Stanford University Press 5:1-65 
Lindsley DH, Brown GM, Muir ID (1969) Conditions of the ferrowollastonite-ferrohedenbergite inversion in the Skaergaard intrusion, east Greenland. Pyroxenes and Amphiboles: Crystal Chemistry and Phase Petrology. Mineral Soc Am Spec Publ $2: 193-201$

Lindsley DH, Burnham CW (1970) Pyroxferroite: Stability and $\mathrm{X}$-ray crystallography of synthetic $\mathrm{Ca}_{0.15} \mathrm{Fe}_{0.85} \mathrm{SiO}_{3}$ pyroxenoid. Science 168:364-367

Lindsley DH, Munoz JL (1969) Subsolidus relations along the join hedenbergite-ferrosilite. Am J Sci (Schairer Vol) 257A: $295-324$

Maresch WV, Mottana A (1976) The pyroxmangite-rhodonite transformation for the $\mathrm{MnSiO}_{3}$ composition. Contrib Mineral Petrol 55:69-79

Mason B (1973) Manganese silicate minerals from Broken Hill, NSW. J Geol Soc Aust 20:397-404

Mason B (1975) Compositional limits of wollastonite and bustamite. Am Mineral 60:209-212

Matsueda H (1973) Iron-wollastonite from the Sampo mine showing properties distinct from those of wollastonite. Mineral J $7: 180-201$

Matsueda $\mathrm{H}$ (1974) Immiscibility gap in the system $\mathrm{CaSiO}_{3}-\mathrm{CaFe}-$ $\mathrm{Si}_{2} \mathrm{O}_{6}$ at low temperatures. Mineral J 7:327-343

Morimoto N, Koto K, Shinohara T (1966) Oriented transformation of johannsenite to bustamite. Mineral J Japan 5:44-64

Morimoto N, Tokonami M (1969) Domain structure of pigeonite and clinoenstatite. Am Mineral 54:725-740

Nesbitt BE, Essene EJ (1980) Metamorphic thermometry and barometry of a portion of the Southern Blue Ridge Province. Am $\mathrm{J}$ Sci (in press)

Ohashi Y, Finger LW (1978) The role of octahedral cations in pyroxenoid crystal chemistry. I. Bustamite, wollastonite and the pectolite-schizolite-serandite series. Am Mineral 63:274-288

Ohashi Y, Finger LW (1975) Pyroxenoids: a comparison of refined structures of rhodonite and pyroxmangite. Carnegie Inst Washington Yearb 74:564-569

Ohashi Y, Kato A, Matsubara S (1975) Pyroxenoids: A variation in chemistry of natural rhodonites and pyroxmangites. Camegie Inst Washington Yearb 74:561-564

Peacor DR, Essene EJ, Brown PE, Winter GA (1978) The crystal chemistry and petrogenesis of a magnesian rhodonite. Am Mineral $63: 1137-1142$
Peters T, Schwender H, Tromsdorff V, Sommerauer J (1978) Manganese pyroxenoids and carbonates: Critical phase relations in metamorphic assemblages from the Alps. Contrib Mineral Petrol 66:383-388

Peters T, Valarelli JV, Coutinho JMV, Sommerauer J, von Raumer J (1977) The manganese deposits of Buritirama (Para, Brazil). Schweiz Mineral Petrogr Mitt 57:313-327

Rapoport PA, Burnham CW (1972) Structural chemistry of bustamite-type pyroxenoids on the wollastonite-hedenbergite join (abstr.). Geol Soc Am Abstr Progr 7:632-633

Ross M, Papike JJ, Shaw KW (1969) Exsolution textures in amphiboles as indicators of subsolidus thermal histories. Pyroxenes and Amphiboles: Crystal Chemistry and Phase Petrology. Mineral Soc Am Spec Publ 2:275-299

Rutstein MS (1971) Re-examination of the wollastonite-hedenbergite $\left(\mathrm{CaSiO}_{3}-\mathrm{CaFeSi}_{2} \mathrm{O}_{6}\right)$ equilibria. Am Mineral 56:20402052

Rutstein MS, White WB (1971) Vibrational spectra of high-calcium pyroxenes and pyroxenoids. Am Mineral 56:877-887

Shimazaki $H$, Bunno $M$ (1978) Subsolidus skarn equilibria in the system $\mathrm{CaSiO}_{3}-\mathrm{CaMgSi}_{2} \mathrm{O}_{6}-\mathrm{CaFeSi}_{2} \mathrm{O}_{6}-\mathrm{CaMnSi}_{2} \mathrm{O}_{6}$. Can Mineral 16:539-545

Smith D (1972) Stability of iron-rich pyroxene in the system Ca$\mathrm{SiO}_{3}-\mathrm{FeSiO}_{3}-\mathrm{MgSiO}_{3}$. Am Mineral 57:1413-1428

Sundius $N(1931)$ On the triclinic manganiferous pyroxenes. Am Mineral 16:41 1-429, 488-518

Tilley CE (1937 a) Pyroxmangite from Inverness-Shire, Scotland. Am Mineral 22:720-727

Tilley CE (1937b) Wollastonite solid solutions from Scawt Hill, Co. Antrim. Mineral Mag 24:569-572

Tilley CE (1948) On iron-wollastonites in contact skarns : an example from Skye. Am Mineral 33:736-738

Valley JW, Bohlen SR (1979) A petrogenetic grid for Adirondack metamorphism (abstr.). Geol Soc Am Abstr Progr 11:57

Winter GA, Essene EJ, Peacor DR (1980) The mineralogy and petrology of the manganese deposit near Bald Knob, North Carolina. I. Mn-carbonates and -pyroxenoids. Am Mineral (in press)

Received March 25, 1980; Accepted June 16, 1980

\section{Note Added in Proof}

Aikawa (Mineral. J. 9, 1979) reports coexisting rhodonite and pyroxmangite which, while plotting within the $\mathrm{Mn}-\mathrm{Mg}-\mathrm{Fe}-\mathrm{Ca}$ chain silicate tetrahedron, further support the direction and magnitude of the lines in Figs. 3 and 4. A recent publication, J. Mineral. Soc. Japan 14, Special Issue $\$ 3,1980$ is an extensive review of manganese mineralogy and has several papers concerning chemical compositions and phase relations for Mn-bearing pyroxenes and pyroxenoids which parallel the results in the present paper. 